\title{
BUCCAL DNA COLLECTION USING TREATED PAPER
}

\author{
Atavliyeva S., Tarlykov P. \\ National Center for Biotechnology \\ 13/5, Korgalzhyn road, Nur-Sultan, 010000, Kazakhstan \\ atavlievas@gmail.com
}

\begin{abstract}
This study presents a domestic kit suitable for the collection of human buccal cells, and long-term storage of nucleic acids on a piece of paper. A filter paper with a density of $70 \mathrm{~g} / \mathrm{m}^{2}$ was selected and treated with chemicals that make up the lysing solution, which contributes to the destruction of cells and prevents bacterial growth. A total of 25 buccal cell samples were collected on the treated paper cards. The samples had a median DNA concentration of $20 \mathrm{ng} / \mu \mathrm{l}($ range $0.5-45 \mathrm{ng} / \mu \mathrm{l})$. The collected DNA samples were tested using a real-time PCR, sequencing of the first hypervariable segment of the human mtDNA control region, and multiplex genotyping of 15 short tandem repeat loci. We conclude that the domestic pretreated cards could be used for collecting and isolating DNA from buccal epithelium for genetic and other applications.
\end{abstract}

Key words: DNA, identification, buccal cells, PCR, fragment analysis

Cost-efficient methods for collecting and storing high-quality DNA are currently in great demand in the life sciences field. The storage of biomaterials on a filter paper carrier has been recently introduced into practice. Buccal cells represent a non-invasive and practical facility for collecting and storing genetic material. There are several manufacturers of buccal epithelium collection and storage kits on the market, one of which is as Whatman ${ }^{\mathrm{TM}}$ FTA $^{\mathrm{TM}}$ (Flinders Technology Associates) Card (GE Healthcare) [1]. These cards are impregnated with a patented mixture of chemicals that make up the lysing solution to destroy cells, prevent the growth of bacteria, and protect DNA from nucleases [2]. An additional advantage of cards is long-term storage compared to brushes for collecting buccal epithelium, for which the recommended storage is no more than 5 days [2,3]. An increasing number of epidemiological studies are associated with the collection and analysis of DNA extracted using FTA cards from various types of biomaterial [4]. The general use of FTA cards in molecular genetics research is the efficiency and ease of use of this method, as well as the minimal cost of DNA isolation significantly expands the range of population screenings [5].

This study presents the development of domestic kit for genetic analysis, including a collection of human buccal cells, and long-term storage of nucleic acids on a piece of paper. The study aimed to conduct laboratory tests and evaluate the DNA concentration from the developed cards. To ensure the quality of the collection, isolation, and storage protocols, samples were genotyped using several methods commonly used in clinical, pharmacogenetic, and forensic experiments. Before the study, approval was received from the local Ethics Committee of the National Center for Biotechnology (protocol no.4, 29.08.2017). The Ethics Committee approved the procedures, the informed consent form, and data collected for the study.

The basis of the kit was selected filter paper with a density of $70 \mathrm{~g} / \mathrm{m}^{2}$. It was 
treated with chemicals that make up the lysing solution (e.g. EDTA, Tris buffer, and NLauroylsarcosine), which contributes to the destruction of cells and prevents bacterial growth. We analyzed a total of 25 buccal cell samples that were brushed with sterile cotton swabs to detach a large number of cells. Ends of the swabs were pressed into the treated paper cards to transfer collected cells. Afterward, the cards were dried for 3 hours. Then, three disks with a diameter of 3-6 mm were cut out with filter puncher, and DNA was eluted into the solution with TE buffer, previously washed twice with $200 \mu \mathrm{l}$ of Milli-Q water. Samples were quantified with a Qubit 2.0 Fluorometer using the Qubit dsDNA HS (High Sensitivity) Assay Kit according to the manufacturer's instructions. Real-time PCR analysis was performed on the $A B O$ of erythrocyte surface proteins gene (rs8176746 A>C), performed on a CFX96 Real-Time System (BioRad). The sequencing of the first hypervariable segment of human mtDNA of 572 nucleotide pairs was conducted using the BigDye Terminator v3.1 Cycle Sequencing Kit (Applied Biosystems) and the ABI 3730xl DNA Analyzer (Applied Biosystems). Multiplex amplification of 15 short tandem repeat (STR) loci plus the Amelogenin genderdetermining marker was performed with the AmpFISTR Identifiler PCR Amplification Kit (Applied Biosystems) using $3130 \mathrm{xl}$ Genetic analyzer and analyzed with GeneMapper 4.0 software (Applied Biosystems).

The samples had a median DNA concentration of $20 \mathrm{ng} / \mu \mathrm{l}$ (range $0.5-45 \mathrm{ng} / \mu \mathrm{l}$ ) for a total sample spot, while DNA concentrations of $0.1-3 \mathrm{ng} / \mu \mathrm{l}$ from a single $3 \mathrm{~mm}$ disk were detected. DNA concentration Real-time PCR was performed on the $A B O$ gene (rs8176746 A>C) and was successful in all samples. The first hypervariable segment of human mtDNA with a product size of $572 \mathrm{bp}$ was successfully amplified. Multiplex genotyping of 15 STR regions and the amelogenin locus was carried out using the AmpFISTR Identifiler assay and the collected 25 DNA samples. An example of an electropherogram with DNA amplification results is shown in Figure 1. 


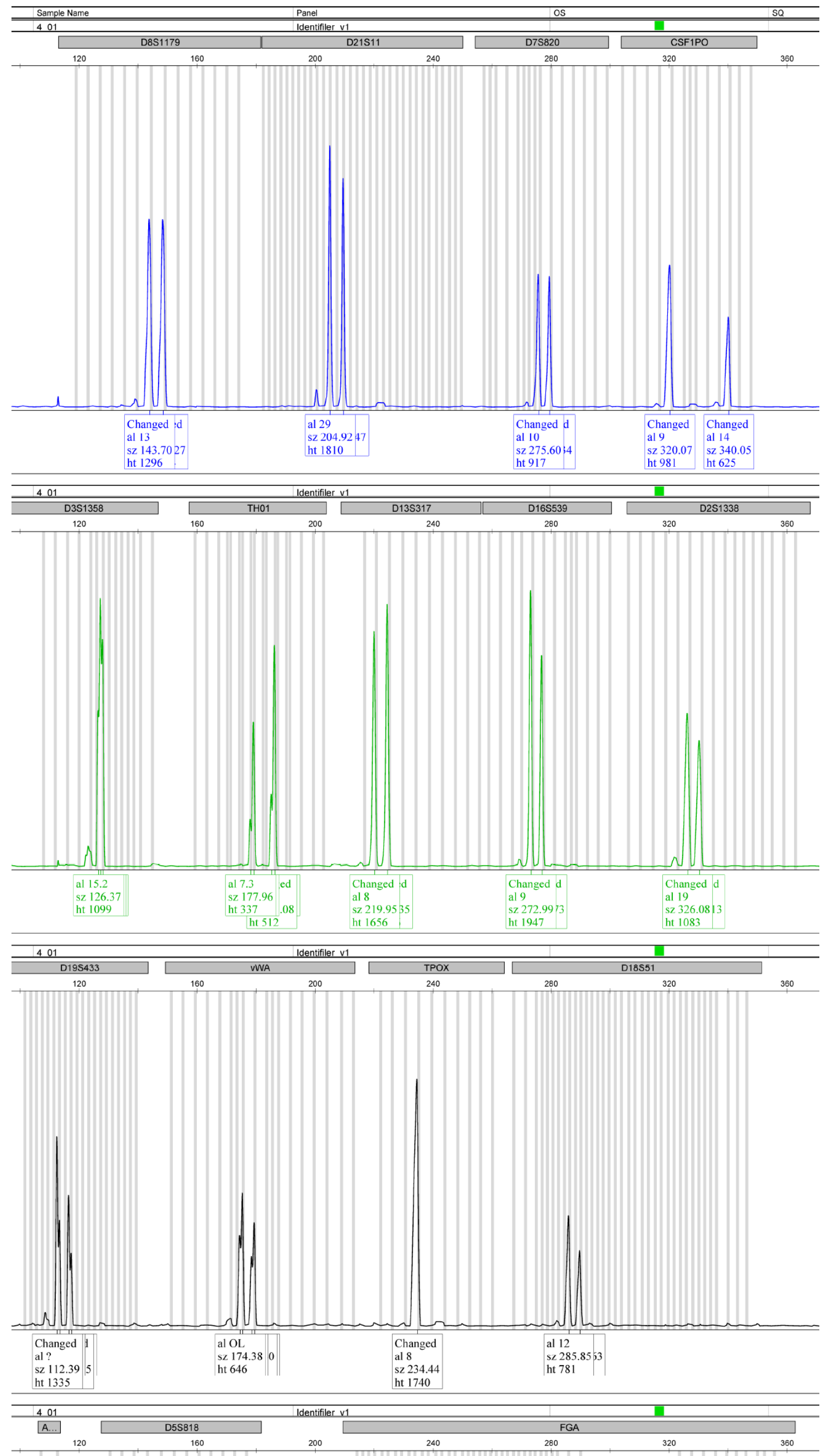


Fig. 1. Electropherogram showing DNA amplification results for the fifteen STR loci and the Amelogenin locus of a buccal sample collected on the pretreated paper. DNA fragments are labeled in FAM dye (blue), VIC dye (green), NED dye (yellow, depicted in black), and PET dye (red). The GeneScan-500 size standard is labeled with LIZ dye (not shown).

In addition, we used GenSaver 2.0 cards (Ahlstrom Munksjo, Germany) to make a comparison testing. All comparisons were adjusted to one 3-mm punch. GenSaver 2.0 cards have produced higher DNA yield, however, STR genotyping and amplification results were similar for both kits. The DNA extracted from the developed cards was of sufficient quality to determine a person's identity using STR profiling. At least 3 years of amplifiable DNA storage within a card at room temperature are expected. As a result, it was confirmed that the paper cards could be used for collecting and isolating DNA from buccal epithelium for genetic and other experiments.

The use of paper cards may dramatically reduce the cost of nucleic acid extraction The commercial filter paper that was used in the study was $50 \$$ per 100 sheets $(45 \times 45 \mathrm{~cm})$ on the market. Our pretreated card together with a sterile cotton swab and homemade buffers will cost less than $0.5 \$$ per sample making it a cost-efficient solution for DNA applications.

\section{Acknowledgments}

This study was supported by the Ministry of Education and Science of the Republic of Kazakhstan (grant no. AP05130240).

\section{REFERENCES}

1. Mas S., Crescenti A., Gasso P. et al. DNA cards: determinants of DNA yield and quality in collecting genetic samples for pharmacogenetic studies. Basic Clin Pharmacol Toxicol., 2007, vol. 101, no 2, pp.132-137. doi: 10.1111/j.17427843.2007.00089.x.

2. Milne, E. et al. Buccal DNA collection: Comparison of buccal swabs with FTA cards. Cancer Epidemiol. Biomarkers Prev., 2006, no 15, pp. 816-819. doi: 10.1158/1055-9965.EPI-05-0753.

3. Beckett S.M., Laughton S.J., Pozza L.D. et al. Buccal swabs and treated cards: Methodological considerations for molecular epidemiologic studies examining pediatric populations // Am. J. Epidemiol., 2008, vol.167, no 10, pp. 1260-1267. doi: 10.1093/aje/kwn012.

4.Atavliyeva S., Mukhamedyarov D., Anuarbekova A., Tarlykov P. Cards for collection of biomaterial samples: areas of application. Eurasian Journal of Applied Biotechnology, 2018, no. 4, pp.11-17.

5. Shao-Ming Wang, Shang-Ying Hu, Wen Chen, Feng Chen, Fang-Hui Zhao, Wei He, Xin-Ming Ma, Yu-Qing Zhang, Jian Wang, Priya Sivasubramaniam and YouLin Qiao. Feasibility and accuracy evaluation of three human papillomavirus assays for FTA card-based sampling: a pilot study in cervical cancer screening. BMC Cancer, 2015, 15:848, pp.1-8. doi: 10.1186/s12885-015-1882-9. 


\title{
ИСПОЛЬЗОВАНИЕ ОБРАБОТАННОЙ БУМАГИ ДЛЯ СБОРА БУККАЛЬНОЙ ДНК
}

\begin{abstract}
АБСТРАКТ
В данном исследовании представлен отечественный набор для сбора буккальных клеток человека и длительного хранения нуклеиновых кислот на бумажном носителе. Была отобрана фильтровальная бумага плотностью 70 г/м2 и обработана химическими веществами, которые составляют лизирующий раствор, что способствует разрушению клеток и предотвращает рост бактерий. Всего на обработанных бумажных карточках было собрано 25 образцов буккальных клеток. Образцы имели средний выход ДНК 20 нг/мкл (диапазон 0,5-45 нг / мкл). Собранные образцы ДНК тестировали с использованием ПЦР в режиме реального времени, секвенирования первого гипервариабельного сегмента человеческой мтДНК человека и мультиплексного генотипирования 15 коротких тандемных повторяющихся локусов. Мы пришли к выводу, что отечественные предварительно обработанные карты могут быть использованы для сбора и выделения ДНК из буккального эпителия для генетических исследований и других применений.

Ключевые слова: ДНК, идентификация, буккальные клетки, ПЦР, фрагментный анализ
\end{abstract}

\section{БУККАЛДЫ ДНК ЖИНАУ ҮШІН ӨНДЕЛГЕН ҚАҒАЗДЫ ПАЙДАЛАНУ}

\section{ТYЙІН}

Бұл зерттеуде адамның буккалды жасушаларын жинау және қағаз бетінде нуклеин қышқылдарын ұзақ сақтау үшін отандық жиынтық ұсынылып отыр. Тығыздығы 70 г/м2 сүзгіш қағаз іріктеліп алынды және жасушалардың бұзылуына ықпал ететін және бактериялардың өсуін алдын алатын лизис ерітіндісін құрайтын химиялық заттармен өңделген. Өңделген қағаз карточкаларда барлығы 25 дана ұрт жасушалары жиналды. ДНК орташа концентрациясы 20 нг/мкл (диапазон 0,5-45 нг/ мкл) құрады. ДНК жиналған үлгілері нақты уақыт режимінде ПТР-ды пайдалана отырып, мтДНҚ бақылау аймағының бірінші гипервариабельді сегментін секвенирлеу және 15 қысқа тандемдік қайталанатын локустарды мультиплексті генотиптеу арқылы сынақтан өтті. Біз отандық өңделген карталар генетикалық зерттеулер мен басқа да қолдануға арналған буккалды қабаттан ДНҚ жинау және бөлу үшін пайдаланылуы мүмкіндігі бар деген қорытындыға келдік.

Негізгі сөздер: ДНҚ, идентификация, буккальды жасушалар, ПТР, фрагментті талдау 